\title{
Growth Performance of Five Bean (Phaseolus spp) Varieties as Influenced by Organic Amendment
}

\author{
${ }^{1}$ EBOIBI, O; ${ }^{2}$ AKPOKODJE, O I; ${ }^{3 *}$ UGURU, H \\ ${ }^{I}$ Department of Mechanical Engineering, Delta State Polytechnic, Ozoro, Delta State Nigeria. \\ ${ }^{2}$ Department of Civil Engineering, Delta State Polytechnic, Ozoro, Delta State Nigeria. \\ ${ }^{3}$ Department of Agricultural and Bio-Environmental Engineering, Delta State Polytechnic, Ozoro, Delta State, Nigeria \\ *Corresponding Author Email: erobo2011@gmail.com
}

\begin{abstract}
The objective of this study was to investigate the influence of organic amendment on the growth performance of five bean varieties and soil chemical characteristics. From the results, the application of soil amendment had significant $(\mathrm{P} \leq 0.05)$ effect on bean plant girth, number of leaves, number of branches, mean number of flowers, total fresh weight and total dry weight, of the bean five varieties planted. The increase in the bean growth observed in this research can be attributed to the improvement of the soil nutrients by the compost manure. The results from this research show that organic manure can be formulated and blended from wood sawdust, palm fruit waste and poultry waste which are chiefly abundant in the Niger Delta region of Nigeria.
\end{abstract}

\section{DOI: https://dx.doi.org/10.4314/jasem.v22i5.29}

Copyright: Copyright (C) 2018 Eboibi et al. This is an open access article distributed under the Creative Commons Attribution License (CCL), which permits unrestricted use, distribution, and reproduction in any medium, provided the original work is properly cited.

Dates: Received: 07 August 2017; Revised: 13 December: 2017; Accepted: 22 January 2018

Keywords: Organic matter, bean, soil amendment, growth and performance

Beans (Phaseolus spp) belong to one of several genera of the flowering plant family Fabaceae, which are used for human or animal food. Beans is an important pulse crop, the consumption of which, both fresh and processed, has tended to increase latterly due to its nutritional values, simple cultivation technology, excellent storage properties, and its wide range of culinary uses. Beans supply a significant amount of protein for a great part of the world population, especially in poor countries where the consumption of animal protein is relatively low; in addition, their high content of protein, carbohydrates, fibres, some minerals and vitamins make beans an excellent nutrient source. (Batista et al., 2010). Lima beans, also called butter beans or butter peas, are highly sensitive to cool weather; plant them well after the first frost. Bush types take 60 to 75 days to mature. Pole types require 90 to 130 days, but the vines grow quickly and up to 12 feet long. Lima are usually green, but there are also some speckled types. Use either fresh or dried in soups, stews, and casseroles. The high level of potassium in honey beans is able to keep the good condition of heart. It is able to regulate blood circulation and avoid the high blood pressure. Honey beans also contain nutrients which are able to activate hormone phytoestrogents. The hormone includes isovlavone which are believed to be able inhibiting harmful chemical in food. The harmful chemical from food is the main culprit of cancer cell formation. Therefore, the honey beans are also powerful to block cancer, especially breast cancer. Cowpea is of major importance to the livelihoods of millions of relatively poor people in less developed countries of the tropics. In fresh form, the young leaves, immature pods, and peas are used as vegetables, while several snacks and main meal dishes are prepared from the grain. All the plant parts that are used for food are nutritious, providing protein, vitamins, and minerals.

Researchers further observed the benefits of compost amendments when added to the soil include $\mathrm{pH}$ depressing and faster infiltration rate due to enhanced soil aggregation (Liang et al., 2011); and the quality of the composted organic residues and the composting method predominantly determine final compost quality and its effect on soil properties. Compost has shown to improve crop productivity and farmers' income in undeveloped countries where soil degradation has led to food shortage (Ouédraogo et al., 2001). The implementation of leguminous fallows has been proposed to increase soil organic matter and available $\mathrm{N}$ in agricultural soils. Leguminous cover crops have been shown to enhance soil organic matter quality by increasing its nitrogen content when compared with non-coordinated fallows (Koutika et al., 2001; Nezomba et al., 2012).

There is paucity of information on the use of wood sawdust, palm fruit waste plus poultry manure as compost manure in bean production. The objective of 
this study was to investigate the influence of formulated (ratio: 50:25:25) organic amendment (wood sawdust: palm fruit bunch waste: poultry waste) on the growth performance of five bean varieties (iron bean, honey bean, brown bean, butter bean and white cowpea) and soil chemical characteristics.

\section{MATERIALS AND METHODS}

The experiment was carried out at the Research Farm of the Delta State Polytechnic, Ozoro, Nigeria. Ozoro is located on latitude $5.544 \mathrm{~N}$, longitude 6.232 East and altitude 14 Meters (45.93 Feet) above sea level. Rainfall distribution pattern in this region is bimodal with peaks in July and September and a short dry spell around mid-August. Ozoro is located in the rain forest vegetation region of Nigeria with temperature of $28 \pm$ $5{ }^{\circ} \mathrm{C}$, according to data from the Delta State polytechnic metrological station.

Experimental setup: A field trial was conducted to evaluate the effects of wood sawdust, palm fruit bunch waste and poultry manure rates on the morphological growth and performance of five varieties of bean (Phaseolus spp). The experiment was carried out at the research farm of Delta State polytechnic, Ozoro. The soil treatment management (STM) lasted for 100 days and included the following design shown in Table 1. The experimental field $50 \mathrm{~m}$ wide $\mathrm{x} 50 \mathrm{~m}$ long would be divided fifteen main blocks according to the number of replicates. Five bean varieties would be planted with each block at a spacing of $0.3 \mathrm{~m}$ on January 02, 2018.

Table 1: Substrate compositions of the different soil treatments

\begin{tabular}{ll}
\hline Treatment & Substrate (Volume ratio) \\
\hline Treatment 1 (T1) & $\begin{array}{l}100 \% \text { natural soil (control) } \\
\text { Treatment 2 (T2) }\end{array}$ \\
& $\begin{array}{l}\text { Natural soil + 10 kg of } \\
\text { compost incorporated }\end{array}$ \\
\hline
\end{tabular}

Composting of the organic manure: The wood sawdust was obtained from local sawmill in Oleh, Delta state, Nigeria; while the palm fruit bunch waste was obtained from the Delta State polytechnic palm oil mill; while poultry waste was obtained from the Delta state polytechnic poultry farm located within the school premises. The three constituents were composed using a mixing ratio of $50 \%: 25 \%: 25 \%$ (volume to volume), using passively aerated static pile method for three months.

Soil sample collection and analysis: Soil samples were collected from the top soil at a depth of $0-15 \mathrm{~cm}$ before the application of the compost manure (wood sawdust + palm fruit bunch waste +poultry manure) to determine the effects of the manure rates on the chemical properties of the soil.
Chemical analysis of the substrates: The analysis of the soil was done at the Thermosteel Nigeria Limited, Warri, Delta state, Nigeria, Research Laboratory. The samples were air dried, ground and passed through a sieve with $2 \mathrm{~mm}$ standard mesh size. Total nitrogen was determined by micro-kjeldahl procedure (Page et al., 1982). Available phosphorus was determined colorimeterically using ascorbic acid method (Murphy and Riley, 1962). Exchangeable potassium was extracted using $1 \mathrm{~N}$ ammonium acetate $\left(\mathrm{NH}_{4} \mathrm{OAC}\right)$ solution and determined by the flame emission spectroscopy as outlined by Anderson and Ingram (1993). Sodium and Copper were determined by the method as described by Chapman (1982). All prepared samples were analysed for the parameters before sowing and after harvest of the beans. The results of the chemical analyses of the soil and the formulated compost manure used for the research are presented in Table 2.

Table 2: Physicochemical properties of the soil and the compost

\begin{tabular}{lll}
\multicolumn{3}{c}{ manure } \\
& \multicolumn{2}{c}{ Level } \\
& Soil sample & $\begin{array}{l}\text { Compost } \\
\text { manure }\end{array}$ \\
\hline Particle size distribution (\%) & & \\
Sand & 40.3 & - \\
Silt & 35.6 & - \\
Clay & 24.1 & - \\
Chemical analysis & & \\
Soil pH $\left(\mathrm{H}_{2} \mathrm{O}\right)$ & 7.75 & 7.90 \\
Total nitrogen (mg/kg) & 0.119 & 0.424 \\
Available Phosphorus (mg/kg) & 0.337 & 0.402 \\
Copper (mg/kg) & 4.911 & 13.224 \\
Nitrate (mg/kg) & 0.303 & 15.820 \\
Sodium (mg/kg) & 450.748 & 953.614 \\
Extractable Potassium (mg/kg) & 687.585 & 8951 \\
\hline
\end{tabular}

Plant growth analysis: Mean girth size $(\mathrm{mm})$, mean number of leaves, fresh weight $(\mathrm{g})$, mean dry weight $(\mathrm{g})$, and mean flowering days $(\%)$ of the plant stock were determined for each bean variety. The emergence days were counted and recorded after $50 \%$ of the seedling emerged as the first date, and the last seed that emerged is recorded the last. The number of leaves from each replication was counted and recorded separately.

After 80 days after planting (DAP) weeks, the whole plants in each replication were harvested for material analysis. The harvested plants were carefully washed with tap water and rinsed with de-ionized water, separated from living roots and shoots for fresh weight recording (Tanner, 1996). Finally, oven dried to constant weight in a forced draft oven at $80^{\circ} \mathrm{c}$ and then bulked for each replication for above ground and below ground dry biomass analysis (Tanner, 1996). Ten replications were taken for each parameter measured. 
Data collection: The bean growth and development parameters were assessed at 30, 30, 40, 50. 60 and 80 days after planting (DAP). Mean stem girth, mean plant branches, mean number of leaves, mean number of flowers, fresh weight $(\mathrm{g})$, and mean dry weight $(\mathrm{g})$ of the plant stock were determined. Each bean variety main girth size was measured by using flexible tape rule; the number of leaves and branches were assessed by visual count of the green leaves and branches.

Data analysis: The response data were analyzed on IBM SPSS Statistics 20. The analysis of variance test (ANOVA) was carried out using the software SPSS 20.0 to examine the effect of compost manure on the growth and development of the five bean varieties (iron, butter, honey, brown and cowpea), and followed by Duncan's test $(\mathrm{p}<0.05)$. The summary of the readings was plotted in Microsoft Excel 2015, and the coefficients of determination and correlation were determined by using the MS Excel 2015 (Microsoft Corporation Redmond, WA 98052).

\section{RESULTS AND DISCUSSION}

Girth size: As sown in Figure 1, the bean varieties grown in the treated soil provided the better results; than their colleagues grown in the control soil that exhibited stunted growth. Our results are in the sane trend with those obtained by Islam et al., 2016 on bush bean, winged bean and yard long bean. In addition, (Ulsido and Meng, 2016) confirmed increase of the grain chickpeas growth rate and yield with the application of coffee pulp compost.

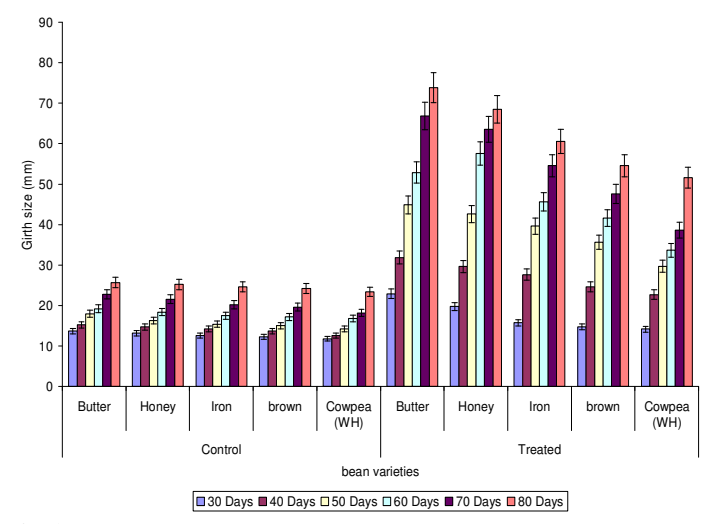

Fig 1: Mean girth size of the bean varieties with growing period under control and treated soil

Number of branches: As presented in Figure 2, it was found that significant increase was achieved in the number of branches of each bean variety with growing period in the treated soil. The results also exhibited that the five bean varieties behaved differentially in term of producing branches per plant (Figure 2). Ulsido and Meng (2016), that found that applying coffee pulp organic matter as a substrate for the growth of chickpeas, increased the number leaves formation rate in chickpeas. The variation in number of branches per plant among the bean varieties can be attributed to the differences in their genetic makeup (Khan et al., 2012). In addition, in terms of the leaf health and vitality, all the bean varieties planted in the treated soil performed better than those planted in the control.

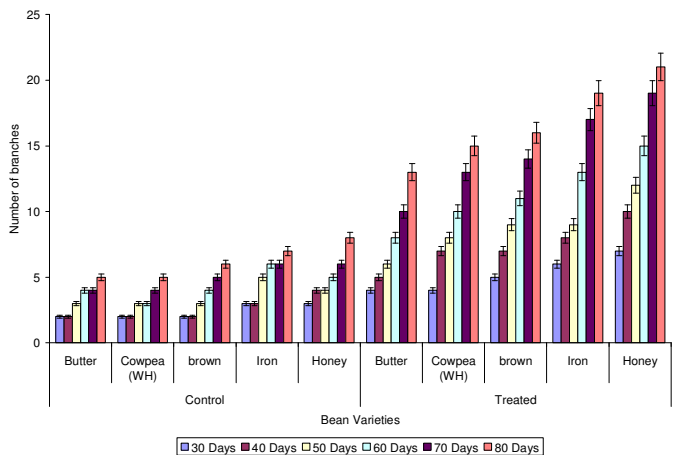

Fig 2: Mean number of branches of the bean varieties with growing period under control and treated soil

\section{Number of leaves}

The mean number of leaves per bean plant was significantly influenced $(\mathrm{P}<0.05)$ both by the bean variety and soil treatment. The maximum number of leaves per plant were recorded for the bean varieties planted in the treated soil sample; while the minimum values were obtained from the bean varieties planted in the control (Figure 3). Roy et al. (2010) observed similar results with Phaseolus vulgaris a bush bean plant.

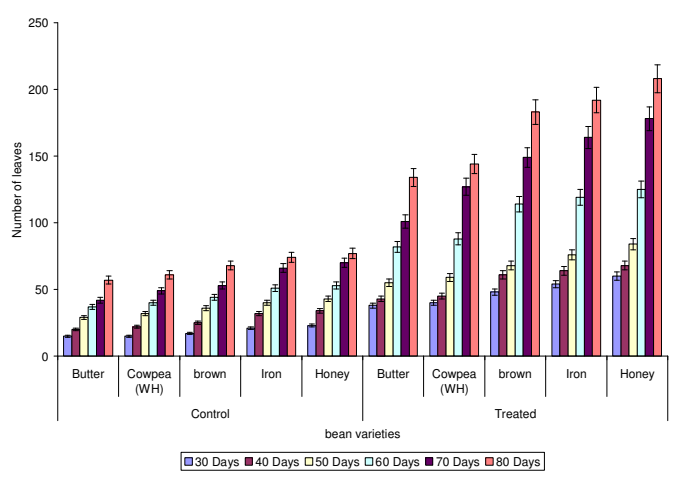

Fig 3: Mean number of leaves of the bean varieties with growing period under control and treated soil

Flowering days (50\%): As showed in Table 3, there was a significant difference between the treated soil sample and the control in flowering of the beans. The increase in the flowering and performance could be attributed to the enhanced nutrient availability of essential nutrients provided by the compost manure. Our results are in accordance with other authours who 
have reported an increase in crop yield because of a nutrient increase induced by organic amendments (Ouédraogo et al., 2001; Altieri and Esposito, 2010).

Total fresh weight: The results showed that compost manure had great effect on vegetative plant growth, in the five bean varieties studied in this research. From the results of the research, poor total fresh weights were obtained in beans planted in the control (Table 4), which could be attributed to the increased availability of the nutrient elements provided by the compost and consequent uptake by the plants. This trend was also reported by Ulsido and Meng (2016) for chickpeas.

Total dry weight: The results obtained from the total dry weight show that bean planted in the treated soil had higher dry weight; and poorer total fresh weights were obtained in beans planted in the control experiment (Table 5). Moyin- jesu (2007) reported that wood ash and cocoa husk were the most effective in improving okra pod weight, pod nutrients, ash content, root length and soil fertility. Ayoola and Adediran (2006) noted that organic manure such as poultry manure, sewage sludge, composted crop residues etc. improved the chemical properties of the soil due to the addition of organic matter. The increase in the soil total nitrogen and organic carbon contents observed in the research may be attributed to the decomposition of the organic matter fraction.

From the Analysis of Variance (ANOVA) table (Table 6 ), the response of the various bean varieties to the addition of the compost manure were significant $(\mathrm{p}<0.05)$ to five of the growth attributes (girth size, number of branches, number of leaves, fresh weight and dry weight). All the parameters investigated increased significantly $(\mathrm{P}<0.05)$ with the application of compost manure as from 30 Days After Planting (DAP) to 80 DAP. As for the flowering parameter, at 80 DAP, flowering observed with beans planted in the treated soil; while the beans with no treatment become stunted without flowers.

Table 3: Total number of flowers produced by each bean variety

\begin{tabular}{llllll|lllll}
\hline \multicolumn{8}{c}{ Control } & \multicolumn{7}{c}{ Treated } \\
Days & Cowpea & Brown & Butter & Iron & Honey & Cowpea & Brown & Butter & Iron & Honey \\
\hline 70 & 0 & 0 & 0 & 0 & 0 & 75 & 81 & 88 & 97 & 109 \\
80 & 0 & 0 & 0 & 0 & 0 & 89 & 96 & 117 & 124 & 151 \\
90 & 0 & 0 & 0 & 0 & 0 & 104 & 116 & 139 & 145 & 163 \\
100 & 0 & 0 & 0 & 0 & 0 & 127 & 138 & 150 & 183 & 200 \\
\hline
\end{tabular}

Table 4: Mean comparison of the fresh weight of the five bean varieties planted under control and treated soil

\begin{tabular}{|c|c|c|c|c|c|c|c|c|c|c|}
\hline \multirow[b]{2}{*}{ Days } & \multicolumn{5}{|c|}{ Control } & \multicolumn{5}{|c|}{ Treated } \\
\hline & Cowpea & Brown & Iron & Honey & Butter & Cowpea & brown & Iron & Honey & Butter \\
\hline 30 & $19.36^{\mathrm{a}}$ & $20.72^{\mathrm{b}}$ & $22.73^{\mathrm{bc}}$ & $24.08^{c}$ & $25.73^{\mathrm{d}}$ & $197.52^{\mathrm{a}}$ & $198.60^{b}$ & $231.88^{b c}$ & $238.4^{\mathrm{c}}$ & $241.66^{\mathrm{d}}$ \\
\hline 40 & $26.24^{\mathrm{a}}$ & $27.59^{b}$ & $28.92^{\mathrm{bc}}$ & $29.04^{c}$ & $31.12^{\mathrm{d}}$ & $296.18^{\mathrm{a}}$ & $299.62^{b}$ & $343.8^{\mathrm{bc}}$ & $417.96^{c}$ & $490.64^{\mathrm{d}}$ \\
\hline 50 & $29.08^{\mathrm{a}}$ & $31.13^{\mathrm{b}}$ & $31.56^{\mathrm{bc}}$ & $34.09^{c}$ & $34.82^{\mathrm{d}}$ & $457.70^{\mathrm{a}}$ & $500.78^{b}$ & $550.6^{\mathrm{bc}}$ & $637.84^{\mathrm{c}}$ & $748.72^{\mathrm{d}}$ \\
\hline 60 & $31.56^{\mathrm{a}}$ & $32.29^{\mathrm{b}}$ & $34.22^{\mathrm{bc}}$ & $36.07^{\mathrm{c}}$ & $36.98^{\mathrm{d}}$ & $693.68^{\mathrm{a}}$ & $742.72^{b}$ & $849.26^{\mathrm{bc}}$ & $1067.8^{\mathrm{c}}$ & $1199.42^{\circ}$ \\
\hline 70 & $33.25^{\mathrm{a}}$ & $37.04^{\mathrm{b}}$ & $39.17^{\mathrm{bc}}$ & $39.28^{\mathrm{c}}$ & $41.83^{\mathrm{d}}$ & $999.72^{\mathrm{a}}$ & $1069^{\mathrm{b}}$ & $1178 b c$ & $1303^{c}$ & 1551.96 \\
\hline 80 & $36.90^{\mathrm{a}}$ & $39.25^{\mathrm{b}}$ & $40.51^{\mathrm{bc}}$ & $42.01^{\mathrm{c}}$ & $45.14^{\mathrm{d}}$ & $1266.4^{\mathrm{a}}$ & $1347^{\mathrm{b}}$ & $1484^{\text {bc }}$ & $1627^{\mathrm{c}}$ & $1757.12^{\circ}$ \\
\hline
\end{tabular}

The means with the same subscripts in the same column are not significantly different $(\mathrm{P}<0.05)$ according to Duncan's multiple ranges test

Table 5: Mean comparison of the dry weight of the five bean varieties planted under control and treated soil

\begin{tabular}{llllll|lllll}
\hline & \multicolumn{3}{c}{ Control } & \multicolumn{5}{c}{ Treated } \\
Days & Cowpea & Brown & Butter & Iron & Honey & Cowpea & Brown & Butter & Iron & Honey \\
\hline 30 & $6.64^{\mathrm{a}}$ & $6.99^{\mathrm{ab}}$ & $7.01^{\mathrm{a}}$ & $7.4^{\mathrm{b}}$ & $9.32^{\mathrm{c}}$ & $68.73^{\mathrm{a}}$ & $70.77^{\mathrm{ab}}$ & $73.88^{\mathrm{a}}$ & $78.97^{\mathrm{b}}$ & $86.66^{\mathrm{c}}$ \\
40 & $7.09^{\mathrm{a}}$ & $7.43^{\mathrm{ab}}$ & $7.85^{\mathrm{a}}$ & $9.1^{\mathrm{b}}$ & $10.24^{\mathrm{c}}$ & $97.96^{\mathrm{a}}$ & $129.62^{\mathrm{ab}}$ & $143.22^{\mathrm{a}}$ & $147.11^{\mathrm{b}}$ & $155.32^{\mathrm{c}}$ \\
50 & $7.87^{\mathrm{a}}$ & $8.04^{\mathrm{ab}}$ & $8.12^{\mathrm{a}}$ & $10.2^{\mathrm{b}}$ & $12.22^{\mathrm{c}}$ & $138.57^{\mathrm{a}}$ & $165.78^{\mathrm{ab}}$ & $170.18^{\mathrm{a}}$ & $194.34^{\mathrm{b}}$ & $200.72^{\mathrm{c}}$ \\
60 & $8.36^{\mathrm{a}}$ & $8.51^{\mathrm{ab}}$ & $8.89^{\mathrm{a}}$ & $11.1^{\mathrm{b}}$ & $13.92^{\mathrm{c}}$ & $183.78 \mathrm{a}$ & $200.72^{\mathrm{ab}}$ & $219.26^{\mathrm{a}}$ & $227.29^{\mathrm{b}}$ & $247.31^{\mathrm{c}}$ \\
70 & $8.92^{\mathrm{a}}$ & $9.1^{\mathrm{ab}}$ & $9.25^{\mathrm{a}}$ & $11.8^{\mathrm{b}}$ & $14.83^{\mathrm{c}}$ & $207.38^{\mathrm{a}}$ & $229.16^{\mathrm{ab}}$ & $257.84^{\mathrm{a}}$ & $272.17^{\mathrm{b}}$ & $292.82^{\mathrm{c}}$ \\
80 & $9.03^{\mathrm{a}}$ & $10.22^{\mathrm{ab}}$ & $10.6^{\mathrm{a}}$ & $12.4^{\mathrm{b}}$ & $15.60^{\mathrm{c}}$ & $226.40^{\mathrm{a}}$ & $259.95^{\mathrm{ab}}$ & $294.08^{\mathrm{a}}$ & $311.58^{\mathrm{b}}$ & $327.12^{\mathrm{c}}$ \\
\hline
\end{tabular}

The means with the same subscripts in the same column are not significantly different $(\mathrm{P}<0.05)$ according to Duncan's multiple ranges test

Table 6: Analysis of variance (ANOVA) of the growth and performance parameters of five bean varieties

\begin{tabular}{lllllll}
\hline Source of variation & df & Girth & Leaves & Branches & Fresh Wight & Dry weight \\
\hline T & 1 & $1.76 \mathrm{E}-131^{*}$ & $1.33 \mathrm{E}-103^{*}$ & $1.14 \mathrm{E}-73^{*}$ & $2.45 \mathrm{E}-35^{*}$ & $1.77 \mathrm{E}-41^{*}$ \\
C & 4 & $3.72 \mathrm{E}-29^{*}$ & $1.22 \mathrm{E}-33^{*}$ & $2.24 \mathrm{E}-27^{*}$ & $2.11 \mathrm{E}-12^{*}$ & $5.71 \mathrm{E}-20^{*}$ \\
G & 5 & $3.66 \mathrm{E}-73^{*}$ & $2.69 \mathrm{E}-94^{*}$ & $1.17 \mathrm{E}-71^{*}$ & $6.22 \mathrm{E}-52^{*}$ & $7.29 \mathrm{E}-71^{*}$ \\
T x C & 4 & $0.000113^{* *}$ & $3.86 \mathrm{E}-11^{*}$ & $6.87 \mathrm{E}-06^{*}$ & $4.21 \mathrm{E}-05^{*}$ & $8.14 \mathrm{E}-09^{*}$ \\
C x G & 20 & $0.286729^{\mathrm{ns}}$ & $2.88 \mathrm{E}-05^{*}$ & $0.030015^{*}$ & $0.004521^{*}$ & $0.06146^{\mathrm{ns}}$ \\
T x G & 5 & $7.08 \mathrm{E}-16$ & $1.79 \mathrm{E}-42^{*}$ & $6.32 \mathrm{E}-12^{*}$ & $3.21 \mathrm{E}-11^{*}$ & $8.66 \mathrm{E}-09^{*}$ \\
T x C x G & 20 & $1.000^{\mathrm{ns}}$ & $0.457^{\mathrm{ns}}$ & $0.980^{\mathrm{ns}}$ & $0.631^{\mathrm{ns}}$ & $0.267^{\mathrm{ns}}$
\end{tabular}

$\mathrm{T}=$ soil treatment $\mathrm{C}=$ bean variety $\mathrm{G}=$ growing period $(\mathrm{DAP}) ;{ }^{*}=$ significant at $\mathrm{p} \leq 0.05 ;$ ns $=$ not significant at $\mathrm{p} \leq 0.05$. 
The means and significant values recorded in Tables 4, 5 and 6 exhibited that all the studied parameters were highly significantly and positively associated with growing period, and soil treatment. The significant difference in the chemical properties of the soil and consequent improved morphological growth rate and performance in all the five bean varieties is an indication that composted wood sawdust, palm bunch waste and poultry manure could be used effectively in soil amendment.

Conclusion: The current study statistically showed that the use of compost made from sawdust, palm fruit branch waste and poultry droppings as an amendment to the soil, improved the chemical properties (nutrient) of the soil. From the results of this research, the application of soil amendment had significant effect on bean plant girth, number of leaves, number of branches, mean number of flowers, total fresh weight and total dry weight, of the bean five varieties planted, which can be attributed to the improvement of the soil nutrients by the application of the compost manure.

\section{REFERENCES}

Anderson, JM; Ingram, JSI (1993). Tropical soil biology and fertility: A Handbook of Methods (2nd edition) $\mathrm{CAB}$ international.

Altieri, R; Esposito, A (2010). Evaluation of the fertilizing effect of olive mill waste compost in short-term crops. Int Biodeterior Biodegradation 64: 124-128.

Ayoola, OT; Adeniran, ON (2006). Influence of poultry manure and NPK fertilizer yield and yield components of crops under different cropping systems in South West Nigeria. Afr. J Biotechnol. 5:1335-1392.

Batista, AK; Prudencio, HS; Fernandes, FK (2010). Changes in the functional properties and antinutritional factors of extruded hard to cook common beans (Phaseolus vulgaris, L.) Journal of Food Science, Vo 1 5, 3.

Chapman, HD (1982). Total Exchangeable bases. In. C.A. Black (ed.), methods of soil analysis, Part 2. ASA, Madison, USA, 9:902-904.

Islam, MA; Boyce, AN; Rahman, M; Azirun, MS; Ashraf, MA (2016). Effects of organic fertilizers on the growth and yield of bush bean, winged bean and yard long bean. Braz. arch. biol. technol. Vol.59:1-7

Khan, AK.; Habibullah, A; Shah, BH; Wahid, MA (2012). Effect of nitrogen fertilizer on the growth of mungbean [vigna radiata (1.)] grown in Quetta. Pak. J. Bot., 44(3): 981-987.

Koutika, LS; Hauser, S; Henrot, J (2001). Soil organic matter assessment in natural regrowth, Pueraria phaseoloides and Mucuna pruriens fallow. Soil Biol Biochem 33: 1095-1101.

Liang, W; Wu, X; Zhang, S; Xing, Y; Wang, R (2011) Effect of organic amendments on soil water storage in the aeolian sandy land of northeast China. Proceedings of the Electrical and Control E Engineering (ICECE). pp. 1538-1540.

Moyin-jesu, EI. (2007). Use of plant residues for improving soil fertility, pod nutrients, root growth and pod weight of okra (Abelmoschus esculentum L.). Bioresource Technology, Vol. 98. Issue 11.

Murphy, J; Riley, J P (1962). A modified single solution method for determination of phosphate in natural waters. Analytica Chimica Acta Journal. 1962;27:31-36.

Ouédraogo, E; Manda, A; Zombre, NP (2011). Use of compost to improve soil properties and crop productivity under low input agricultural system in West Africa. Agric. Ecosys. Environ.. 84:259-266.

Nezomba, H; Tauro, TP; Mtambanengwe. P; Mapfumo, $P$ (2012). Indigenous legume fallows (indifallows) as an alternative soil fertility resource in smallholder maize cropping systems. Field Crops Res.115: 149157.

Page, JR.; Miller, RH; Keeney, DR; Baker, DE; Roscoe Ellis, JR; Rhoades, JD (1982). Methods of Soil Analysis 2: Chemical and Microbiology Properties, 2nd ed. Madison, Wisconsin, U.S.A.

Roy, S; Arunachalama, K; Dutta, BK; Arunachalam, A (2010). Effect of organic amendments of soil on growth and productivity of three common crops viz. Zea mays, Phaseolus vulgaris and Abelmoschus esculentus. Appl. Soil Ecol., 45: 78-84.

Tanner, CC (1996). Plants for constructed wetland treatment systems- A comparison of the growth and nutrient. Ecological Engineering. 1996, vol. 7: pp. 59-83.

Ulsido, MD; Meng, L (2016). Effect of organic matter from coffee pulp compost on yield response of chickpeas (cicer arietinum 1.) in Ethiopia. Engineering for Rural Development. 1339 - 1347 